\title{
EXTRASKELETAL OSTEOCHONDROMATA
}

\author{
D. W. Purser, Manchester. England
}

From the University Department of Orthopaedic Surgery, Manchester Royal Infirmary

Bone-forming tumours in extraskeletal tissues are rare. Stout (1953) found only eighty-five such growths among 7.337 benign mesenchymal tumours of "soft " tissues in the records of the Laboratory of Surgical Pathology of Columbia University during forty-five years. Osteomata have been described in the breast (Cooper 1829, Robinson and Spencer 1950. Ling and Stewart 1955), in retroperitoneal tissues (Kretschmer 1938. Wilson 1941) and even in the tongue (Witchell 1949). A patient of Robillard's (1941) had an ossification of the infrapatellar pad of fat, like the intracapsular, extrasynovial masses of bone and cartilage that Kautz (1945) considered to be osteomata. Kautz attributed the original description of such tumours to Kienbock, who is quoted as having found them in other joints than the knee. Geschickter and Copeland (1949) mentioned three osteochondromata of bursal origin, and twenty-two arising in tendons just above their osseous insertion.

From this review it appears that extraskeletal osteomata and osteochondromata can occur at many sites. The following two examples appear to be the first to be described in the foot.
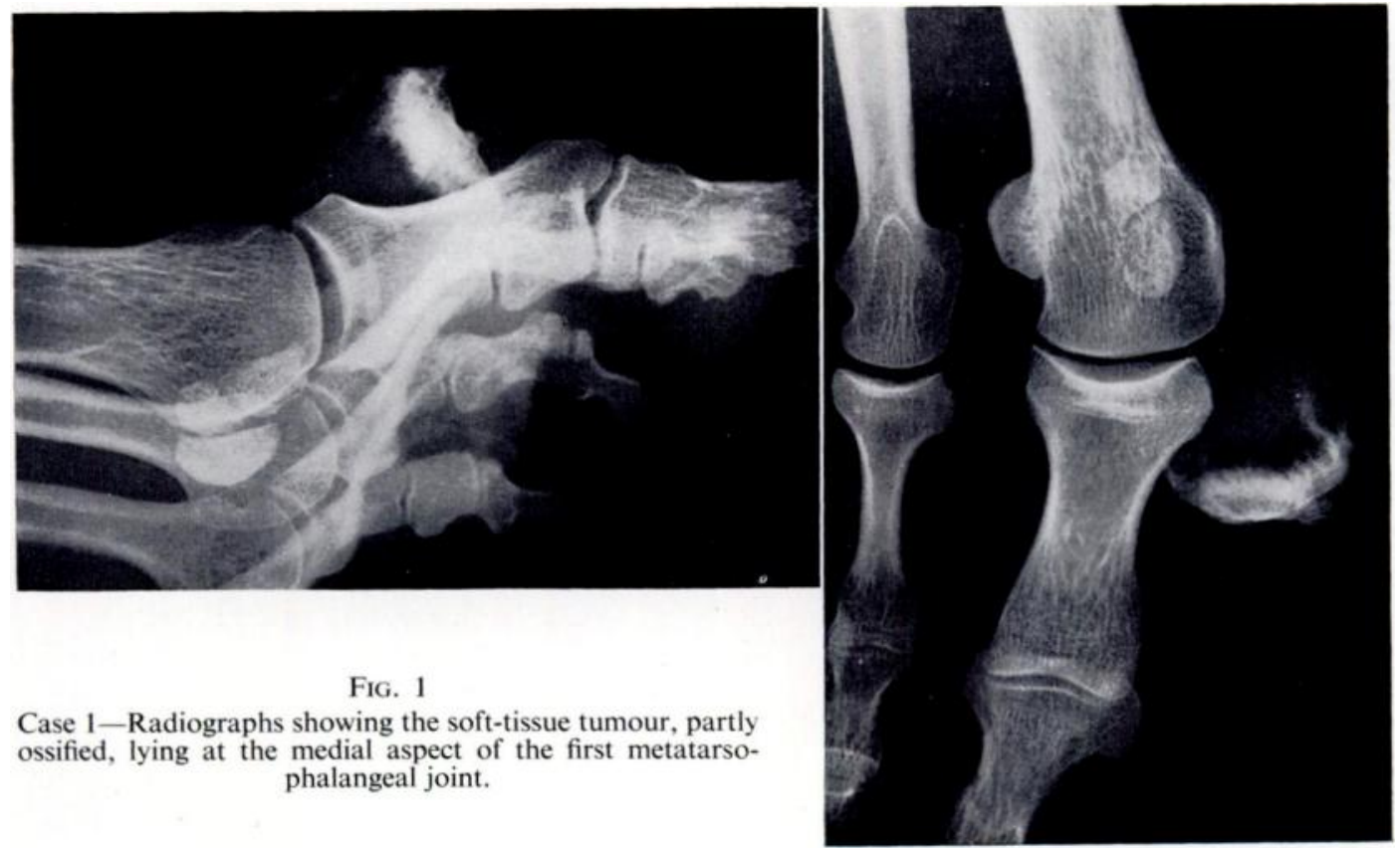

Case 1-Radiographs showing the soft-tissue tumour, partly ossified, lying at the medial aspect of the first metatarsophalangeal joint.

\section{CASE REPORTS}

Case 1 (Patient of Mr R. Broomhead)-A woman aged thirty-nine years attended hospital with a painless swelling of her foot. The swelling had been present for nine months and was gradually enlarging. It was a firm mass, one inch across, at the medial aspect of the first metatarso-phalangeal joint. It could be moved over the deeper structures. Radiographs (Fig. 1) showed a round soft-tissue swelling which was partly ossified. 
The tumour was excised. It was lobulated, and its deep surface formed one wall of a bursa between it and the joint capsule. Histologically the tumour was a simple osteochondroma.

Case 2 (Patient of $\mathrm{Mr}$ D. Ll. Griffiths)-A man aged fifty-three years complained of pain under the forefoot. The pain was relieved by wearing a sandal, but was accentuated by treading on anything hard. A callosity was present under the head of the fourth metatarsal. Radiographs showed a bony opacity in the soft tissues (Fig. 2). Through a curved incision

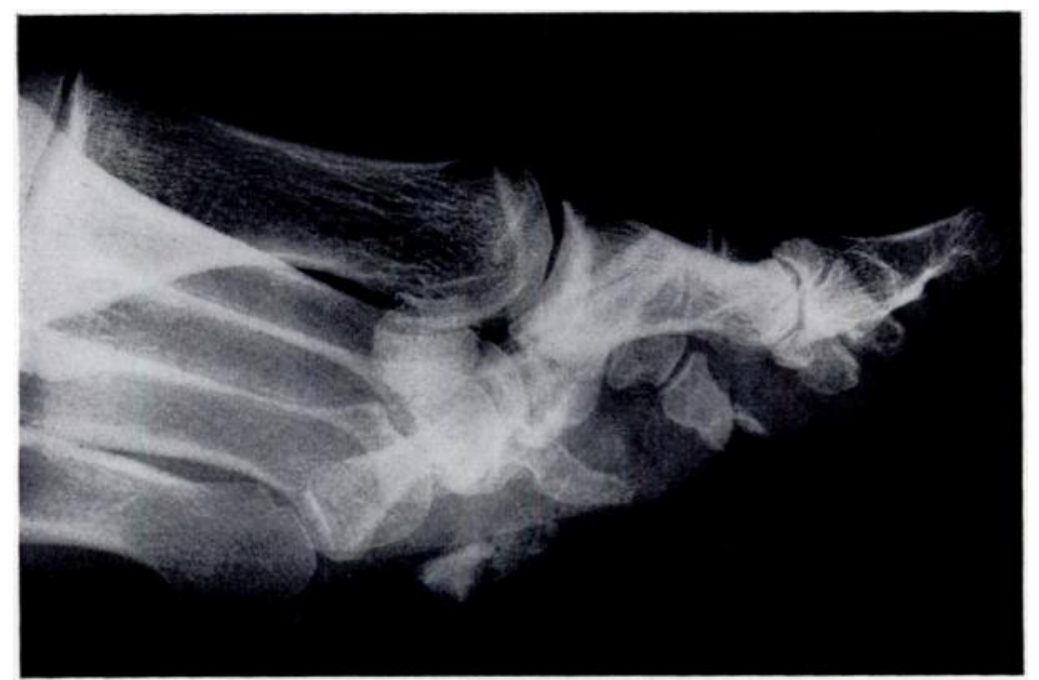

Fig. 2

Case 2-Radiographs showing the area of ossification superficial to the head of the fourth metatarsal.

skirting the callosity the bony tumour was removed. It lay in the subcutaneous tissue, and between it and the underlying tendons was a small bursal cavity. Structurally, the tumour consisted mainly of cancellous trabeculae, in many of which were islands of cartilage. There was a complete capsule of fibrous tissue, but at one aspect, that towards the bursa, there was a transition from fibrous tissue to fibrocartilage, to the cartilage which adjoined the bony trabeculae.

\section{DISCUSSION}

The large proportion of cartilage present in the first of these tumours justifies its classification as an osteochondroma. In the second case there was a preponderance of bone. Such tumours have been described by previous authors as osteomata. Nevertheless the presence of cartilage in many of the cancellous trabeculae indicates that growth has occurred by ossification of a cartilaginous primordium. They are, therefore, better described as osteochondromata.

These cases are not examples of heterotopic ossification, for in that process bone is formed directly from fibrous tissue, and cartilage is not present (Geschickter and Copeland 1949). Furthermore, the clinical state and history of these patients never suggested any previous necrosis, scarring or calcification, the usual basis of heterotopic bone formation.

I thank Mr D. Ll. Griffiths and Mr R. Broomhead for their permission to publish the cases which form the basis of this paper.

\section{REFERENCES}

CoOper, Sir A. (1829): Illustrations of the Diseases of the Breast, p. 64. London: Longman, Rees, Orme, Brown \& Green.

Geschickter, C. F., and Copeland, M. M. (1949): Tumors of Bone. Third edition. Philadelphia, London, Montreal: J. B. Lippincott Company. 
Kautz, F. G. (1945): Capsular Osteoma of the Knee Joint. Report of Four Cases. Radiology, 45, 162.

Kretschmer, H. L. (1938): Retroperitoneal Pararenal Osteoma. Surgery, Gynecology and Obstetrics, $67,108$. LING, W. H. G. M., and STewART, I. S. (1955): A Bony Tumour of the Breast. British Medical Journal, ii, 364. RobillaRd, G. L. (1941): Ossification of Infrapatellar Bursae and Fat Pad. American Journal of Surgery, N.S. 51, 442.

Robinson, R. H. O. B., and Spencer, H. (1950): A Cancellous Osteoma in the Breast. British Journal of Surgery, 37, 481.

Stout, A. P. (1953): Tumors of the Soft Tissues. Atlas of Tumor Pathology, Section ii, Fascicle 5. Washington: Armed Forces Institute of Pathology.

Wilson, H. (1941): Extraskeletal Ossifying Tumors. Annals of Surgery, 113, 95.

Witchell, I. S. (1949): Osteoma of the Tongue. Archives of Otolaryngology, 50, 453. 